\title{
GENERALIZED SCALAR PWM ALGORITHMS FOR DIODE CLAMPED MULTILEVEL INVERTER FED VECTOR CONTROLLED DRIVES
}

\author{
Pasupuleti RAMA MOHAN*, Teegala BRAHMANANDA REDDY**, Mallapu VIJAYA KUMAR ${ }^{* * *}$ \\ "EEE Department, Krishna's Pragati Institute of Technology, Rajahmundry, Andhra Pradesh, India, \\ E-mail: rammohan_cdp@yahoo.co.in \\ **EEE Department, G. Pulla Reddy Engineering College, Kurnool, Andhra Pradesh, India, E-mail: tbnr@rediffmail.com \\ ${ }^{* * *}$ EEE Department, JNTUA College of Engineering, Ananthapur, Andhra Pradesh, India, E- mail: mvk_2004@rediffmail.com
}

\begin{abstract}
This paper presents simple generalized scalar PWM algorithms for three and five-level inverter fed vector controlled drive. The proposed PWM technique uses the notion of imaginary switching times and hence does not require sector and reference voltage vector calculations. Based on the magnitude tests, the minimum and maximum times will be calculated. From which the generalized offset time expression is derived. By varying a constant between 0 and 1 in offset expressions, various PWM methods such as continuous and discontinuous PWM techniques are derived. Thus, the all PWM techniques brought under one umbrella. Moreover, the same generalized PWM approach can be easily extended to multilevel inverters by increasing the number of carrier signals. To evaluate the performance of proposed PWM technique, numerical simulation studies have been carried out on multilevel inverter fed vector controlled drive in MATLAB environment. From the results, it is observed that when compared with continuous modulating PWM technique discontinuous modulating signal based PWM techniques give reduced switching losses for same switching frequency. Moreover, the quality of waveforms is increased as the number of level increases.
\end{abstract}

Keywords: generalized PWM, multilevel inverter, scalar PWM, vector control

\section{INTRODUCTION}

Nowadays, the vector controlled drives are becoming popular for high-performance industry applications, vehicle applications, etc. With the help of vector control technique, the induction motor will be operated as a separately excited dc motor by achieving the decoupled control. However, the classical vector control gives variable switching frequency operation due to the hysteresis controllers. Moreover, the 2-level inverter based vector controlled drive applications are limited to low power applications [1-6]. Hence, to overcome these drawbacks, the PWM techniques based multilevel inverter fed drives became popular.

The multilevel inverter topologies are gaining importance in medium and high power applications. Different multilevel inverter configurations like diode clamped multi level inverter, capacitor clamped multilevel inverter and cascaded H-bridge multilevel inverter topologies were proposed in literature [7-9]. Though the cascaded multilevel inverter topology [10] has many advantages when compared with diode clamped multilevel inverter [11], the cascaded H-bridge topology requires separate voltage sources for its operation. So, in applications where separate DC-sources are not available, diode clamped multilevel inverter is gaining importance [11].

In literature, different PWM techniques based on carrier comparison approach [12-13] and space vector approaches [14-15] were proposed for multilevel inverter for the control of output voltage and frequency. The PWM techniques discussed in [12] could able to control the output parameters but generate low quality output voltage. In order to improve the output voltage quality space vector based PWM technique is presented [14-15]. In [16] authors proposed hybrid PWM technique using current ripple analysis for the improvement of quality of output voltage and reduced current ripple. These space vector based PWM techniques are complex for real time implementation. Because, this approach requires reference voltage vector calculation and sector information. Moreover, the complexity increases as number of levels increases due to the increment in number of voltage space vectors.

To reduce the complexity involved in space vector based PWM techniques simple scalar based implementation of PWM techniques for conventional twolevel inverter configuration are presented in [17-20]. These PWM techniques do not require sector identification. In paper [20] different continuous and discontinuous modulating signal based PWM techniques were presented for conventional two-level inverter topology for the improvement in quality of output voltage, reduce current ripple and reduce switching losses. In this paper the scalar based continuous and discontinuous PWM techniques are employed for the three-level and five-level diode clamped multilevel inverter configuration for the improvement in quality of output voltage and reduce the switching losses.

\section{SCALAR PWM TECHNIQUE FOR N-LEVEL DIODE CLAMPED MULTILEVEL INVERTER}

The circuit topologies of a phase or leg in three and five-level diode clamped multilevel inverters are shown in Fig. 1. From which, it is observed that for an $\mathrm{N}$ level inverter $2(\mathrm{~N}-1)$ switches are present in one leg. In Fig. 1(a), the dc-bus voltage is split into three levels by two series-connected bulk capacitors, $\mathrm{C}_{1}, \mathrm{C}_{2}$. The key components that distinguish this circuit from a conventional two-level inverter are $\mathrm{D}_{1}$ and $\mathrm{D}^{\prime}{ }_{1}$. The potential across $\mathrm{V}_{\mathrm{ao}}$ is called as pole voltage, $\mathrm{V}_{\mathrm{an}}$ is called as the phase voltage ( $\mathrm{n}$ is the neutral point of star connected load of induction motor) and $\mathrm{V}_{\mathrm{ab}}$ is called as line voltage. The output pole voltages with different switching combinations are given in Table 1 and Table 2 . 


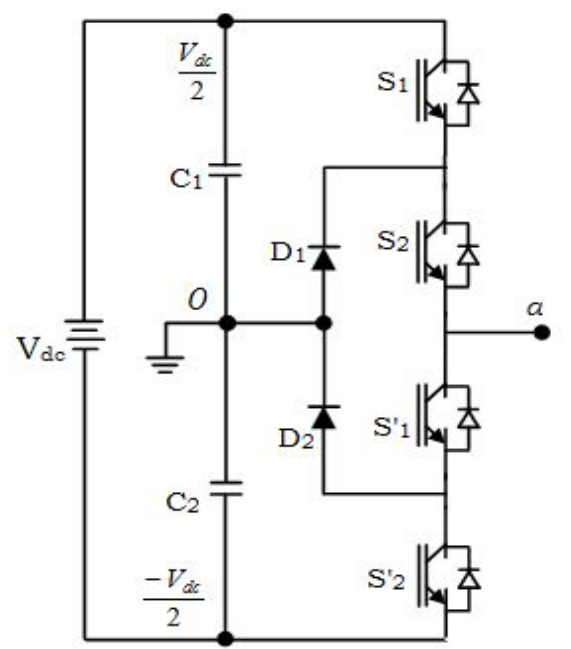

(a)

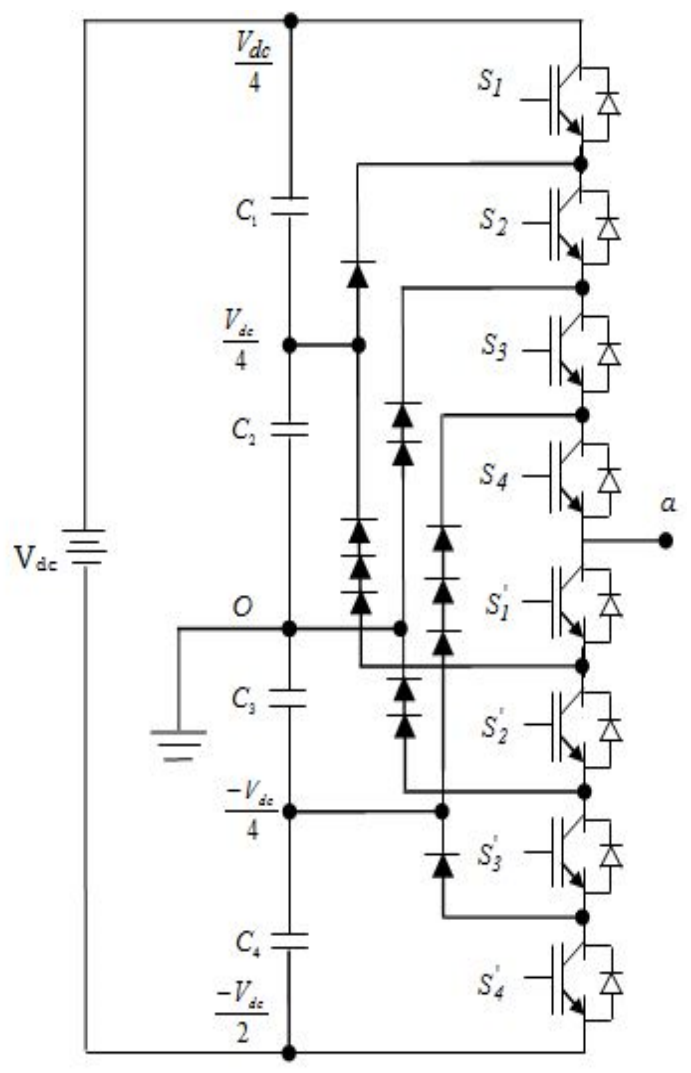

(b)

Fig. 1 Diode-clamped multilevel inverter circuit topologies (a) three-level (b) five-level

From the Table 1 and Table 2, it is observed that the circuit configuration shown in Fig. 1(a) generates three different voltage levels as $\mathrm{V}_{\mathrm{dc}} / 2,0,-\mathrm{V}_{\mathrm{dc}} / 2$ in the pole voltage and the circuit configuration given in Fig. 1(b) generates five different levels as $\mathrm{V}_{\mathrm{dc}} / 4, \mathrm{~V}_{\mathrm{dc}} / 2,0,-\mathrm{V}_{\mathrm{dc}} / 4$, $\mathrm{V}_{\mathrm{dc}} / 2$ in the output pole voltage. Hence, the circuit configuration shown in Fig. 1(a) and Fig. 1(b) are called as three- level and five- level inverter configurations. When the inverters are operated with switching states given in Table 1 and Table 2, an uncontrolled output voltage is generated.
Table 1 Switching combination in three-level diode clamped inverter

\begin{tabular}{|c|c|}
\hline Switching combinations & Pole voltage \\
\hline $\mathrm{S}_{1}$ and $\mathrm{S}_{2}$ are ON & $\mathrm{V}_{\mathrm{dc}} / 2$ \\
$\mathrm{~S}_{1}{ }^{\prime}$ and $\mathrm{S}_{2}{ }^{\prime}$ are OFF & $-\mathrm{V}_{\mathrm{dc}} / 2$ \\
\hline $\mathrm{S}_{1}$ and $\mathrm{S}_{2}$ are OFF \\
$\mathrm{S}_{1}{ }^{\prime}$ and $\mathrm{S}_{2}{ }^{\prime}$ are ON & 0 \\
\hline $\begin{array}{c}\mathrm{S}_{1}{ }^{\prime} \text { and } \mathrm{S}_{2} \text { are ON } \\
\mathrm{S}_{1} \text { and } \mathrm{S}_{2}{ }^{\prime} \text { are OFF }\end{array}$ & 0 \\
\hline $\mathrm{S}_{1}{ }^{\prime}$ and $\mathrm{S}_{2}$ are OFF \\
$\mathrm{S}_{1}$ and $\mathrm{S}_{2}{ }^{\prime}$ are ON
\end{tabular}

Table 2 Switching combination in five-level diode clamped inverter

\begin{tabular}{|c|c|}
\hline Switching combinations & Pole voltage \\
\hline $\begin{array}{c}\mathrm{S}_{1}, \mathrm{~S}_{2}, \mathrm{~S}_{3} \text { and } \mathrm{S}_{4} \text { are ON } \\
\mathrm{S}_{1}^{\prime}, \mathrm{S}_{2}^{\prime}, \mathrm{S}_{3}^{\prime} \text { and } \mathrm{S}_{4}^{\prime} \text { are OFF }\end{array}$ & $\mathrm{V}_{\mathrm{dc}} / 2$ \\
\hline $\begin{array}{c}\mathrm{S}_{1}^{\prime}, \mathrm{S}_{2}, \mathrm{~S}_{3} \text { and } \mathrm{S}_{4} \text { are ON } \\
\mathrm{S}_{1}, \mathrm{~S}_{2}^{\prime}, \mathrm{S}_{3}^{\prime} \text { and } \mathrm{S}_{4}^{\prime} \text { are OFF }\end{array}$ & $\mathrm{V}_{\mathrm{dc}} / 4$ \\
\hline $\begin{array}{c}\mathrm{S}_{1}^{\prime}, \mathrm{S}_{2}^{\prime}, \mathrm{S}_{3} \text { and } \mathrm{S}_{4} \text { are ON } \\
\mathrm{S}_{1}, \mathrm{~S}_{2}, \mathrm{~S}_{3}^{\prime} \text { and } \mathrm{S}_{4}^{\prime} \text { are OFF }\end{array}$ & 0 \\
\hline $\begin{array}{c}\mathrm{S}_{1}^{\prime}, \mathrm{S}_{2}^{\prime}, \mathrm{S}_{3}^{\prime} \text { and } \mathrm{S}_{4} \text { are ON } \\
\mathrm{S}_{1}, \mathrm{~S}_{2}, \mathrm{~S}_{3} \text { and } \mathrm{S}_{4}^{\prime} \text { are OFF }\end{array}$ & $-\mathrm{V}_{\mathrm{dc}} / 4$ \\
\hline $\begin{array}{c}\mathrm{S}_{1}^{\prime}, \mathrm{S}_{2}^{\prime}, \mathrm{S}_{3} \text { and } \mathrm{S}_{4}^{\prime} \text { are ON } \\
\mathrm{S}_{1}, \mathrm{~S}_{2}, \mathrm{~S}_{3} \text { and } \mathrm{S}_{4} \text { are OFF }\end{array}$ & $-\mathrm{V}_{\mathrm{dc}} / 2$ \\
\hline
\end{tabular}

For the control of output voltage and frequency, different PWM techniques are employed for multilevel inverters. In carrier comparison approach to generate control signals for two level inverter one carrier signal is used. Similarly, to generate control signals for N-level inverter N-1 level shifting carrier signal are required. Hence, the three-level inverter requires two level shifting carrier signals and five-level inverter requires four level shifting carrier signals. The intersection point of carrier signals with reference signals gives the switching instants. The realization of carrier comparison approach for the generation of control signals to all top switches for three and five level inverter configurations are shown in Fig. 2.

To generate control signals for 3-phase multilevel inverter configuration, three reference signals are considered as given in (1).

$$
\begin{gathered}
V_{i}=V_{r e f} \cos (\theta-2(r-1) \pi / 3) \\
i=a, b, c \text { and } r=1,2,3
\end{gathered}
$$

From these instantaneous reference signals $\left(\mathrm{V}_{\mathrm{a}}, \mathrm{V}_{\mathrm{b}}, \mathrm{V}_{\mathrm{c}}\right)$ the imaginary switching times can be directly calculated as defined in (2) [20].

$T_{i n}=\frac{V_{i}}{V_{d c}} T_{s} \quad i=a, b, c$

The imaginary switching times may be positive or negative, which depend on reference signals. Hence, these switching times are called as imaginary switching times. From these imaginary switching times, the modulating signals can be generated using (3). 

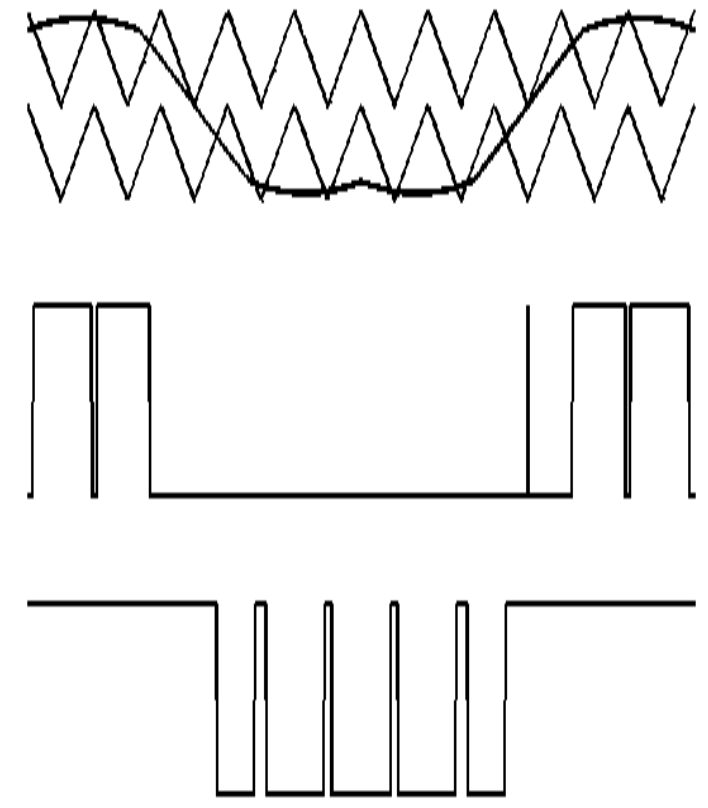

(a)

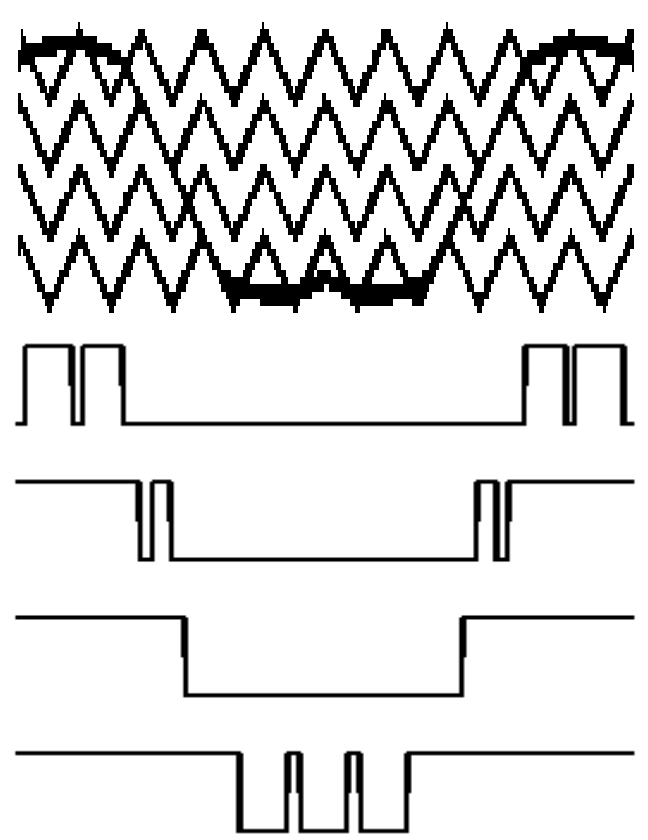

(b)

Fig. 2 Realization of carrier comparison approach for (a) three-level inverter (b) five-level inverter

$V_{i n}^{*}=\frac{V_{d c}}{2}\left(\frac{T_{g i}}{T_{s} / 2}-1\right)$

where

$$
\begin{aligned}
& \begin{array}{l}
T_{g i}=T_{\text {in }}+T_{s}\left(1-k_{o}\right)+\left(k_{o}-1\right) T_{\max }-k_{o} T_{\min } \\
\quad=T_{\text {in }}+T_{\text {offset }}
\end{array} \\
& T_{\text {offset }}=T_{s}\left(1-k_{o}\right)+\left(k_{o}-1\right) T_{\max }-k_{o} T_{\min }
\end{aligned}
$$

Now by varying $\left(\mathrm{k}_{0}\right)$ between 0 and 1 in (4), various offset times $\left(\mathrm{T}_{\text {offset }}\right)$ can be generated. This gives various types of continuous and discontinuous modulating signals. The constant $\mathrm{k}_{\mathrm{o}}$ value to generate different continuous and discontinuous PWM techniques are given in Table 3. The obtained new reference signals along with old reference signals for different values of $\mathrm{k}_{\mathrm{o}}$ are shown in Fig. 3.

Table 3 Generation of various PWM algorithms by varying $\mathrm{k}_{0}$ value

\begin{tabular}{|c|l|}
\hline $\begin{array}{c}\text { PWM } \\
\text { Algorithm }\end{array}$ & \multicolumn{1}{|c|}{$\mathbf{K}_{\mathbf{0}}$ Value } \\
\hline SVPWM & 0.5 \\
\hline DPWMMIN & 1 \\
\hline DPWMMAX & 0 \\
\hline DPWM0 & $\begin{array}{l}\text { if } T_{\max , x}+T_{\min , x}<0 \Rightarrow k_{o}=0 \\
\text { if } T_{\max , x}+T_{\min , x} \geq 0 \Rightarrow k_{o}=1\end{array}$ \\
\hline DPWM1 & $\begin{array}{l}\text { if } T_{\max }+T_{\min ,}<0 \Rightarrow k_{o}=1 \\
\text { if } T_{\max }+T_{\min } \geq 0 \Rightarrow k_{o}=0\end{array}$ \\
\hline
\end{tabular}

\begin{tabular}{|l|l|}
\hline DPWM2 & if $T_{\max , x}+T_{\min , x}<0 \Rightarrow k_{o}=1$ \\
& if $T_{\max , x}+T_{\min , x} \geq 0 \Rightarrow k_{o}=0$ \\
\hline DPWM3 & if $T_{\max }+T_{\min ,}<0 \Rightarrow k_{o}=0$ \\
& if $T_{\max }+T_{\min } \geq 0 \Rightarrow k_{o}=1$ \\
\hline
\end{tabular}

These modulating signals in Fig. 3 are compared with common level shifting carrier signal as shown in Fig. 2 to generate control signals for three level and five level inverter configuration.
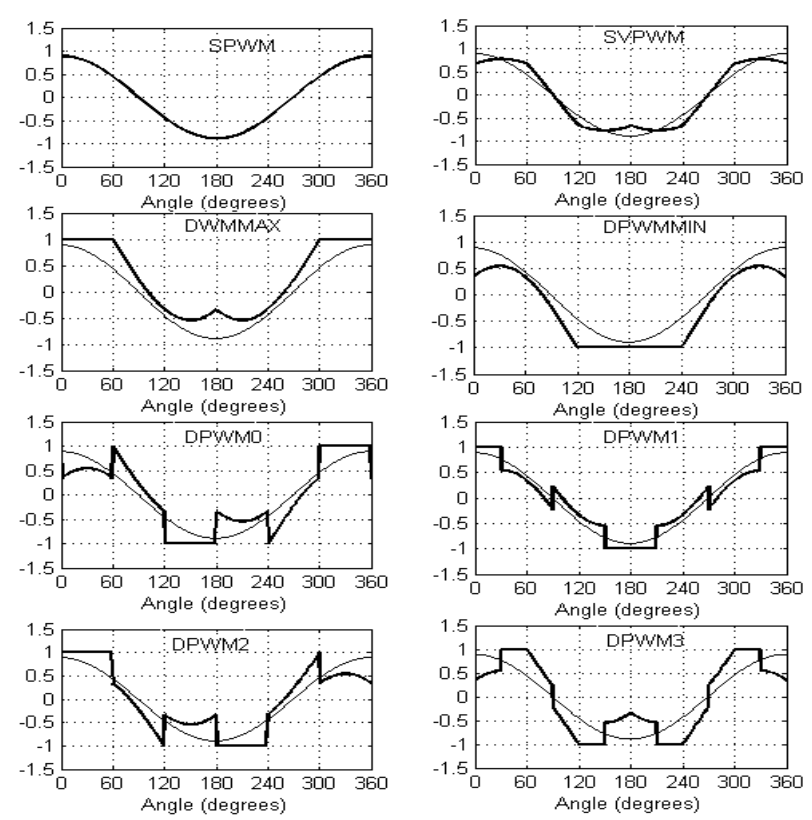

Fig. 3 Different types of continuous and discontinuous modulating signals 


\section{VECTOR CONTROLLED MULTILEVEL INVERTER FED INDUCTION MOTOR DRIVE}

In vector controlled drive, to achieve decoupled control between torque and flux, the stator current vector is resolved into $i_{\mathrm{qs}}$ and $\mathrm{i}_{\mathrm{ds}}$. The general torque expression of induction motor drive in terms of $\mathrm{d}$ - and q-axes currents is expressed as in (5).

$T e=\frac{3}{2} \frac{P}{2} \frac{L_{m}}{L_{r}}\left(\psi_{d r} i_{q s}-\psi_{q r} i_{d s}\right)$

In order to get decoupled control, rotor flux is aligned along d-axis so that the q-axis flux component becomes zero. Hence, the torque equation given by (5) can be modified as in (6)

$T e=\frac{3}{2} \frac{P}{2} \frac{L_{m}}{L_{r}}\left(\psi_{d r} i_{q s}\right)$

The rotor flux linkages is given by (7)

$\psi_{d r}=L_{m} i_{d s}$

From (6) and (7) it is observed that to control torque $\mathrm{I}_{\mathrm{qs}}$ is varied and to control flux $i_{\mathrm{ds}}$ is varied. As the vector control uses the synchronous reference frame, the instant angle between the synchronous frame and stator frame needs to be calculated. This angle equals to the position angle of the rotor flux vector $\left(\theta_{s}\right)$. If the $\theta_{s}$ is calculated, then all quantities can be transformed on to the synchronously rotating reference frame, in which all quantities looks like dc quantities. The reference angle can be calculated using (8).

$\theta_{s}=\theta_{r}+\theta_{s l}=\int\left(\omega_{r}+\omega_{s l}\right) d t=\int \omega_{s}$

where $\omega_{r}$ is the rotor speed and $\omega_{s l}$ is the slip speed which can be calculated given as in (9).

$\omega_{s l}=\frac{L_{m} R_{r}}{L_{r} \lambda_{r}} i_{q s}$

Using the above discussed concept and equations, the block diagram of vector controlled induction motor drive can be given as in Fig. 4.

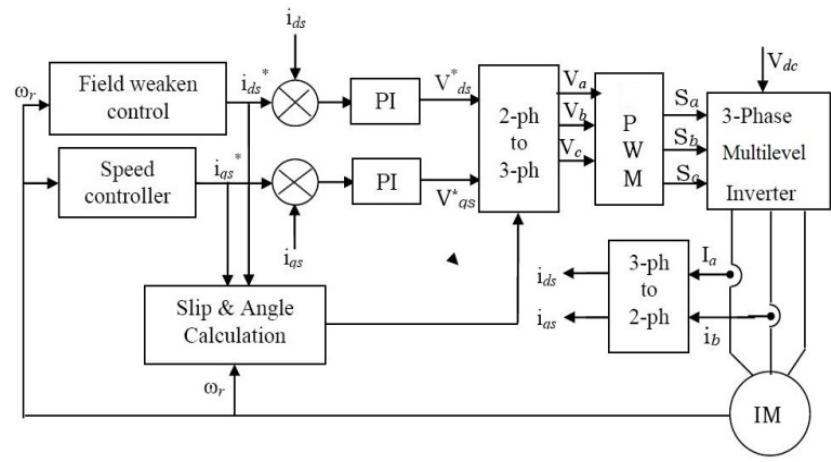

Fig. 4 Block diagram of vector controlled based multilevel inverter fed IM drive
In the block diagram of vector control shown in Fig. 4, from the 2-phase to 3-phase transformation block three reference signals $\mathrm{V}_{\mathrm{a}}, \mathrm{V}_{\mathrm{b}}, \mathrm{V}_{\mathrm{c}}$ are derived and these are fed to PWM block to generate control signals for multilevel inverter. Various types of continuous and discontinuous modulating signal can be derived using these three reference signals. In the PWM block the obtained new reference signals are compared with carrier signals to generate control signals $\left(\mathrm{S}_{\mathrm{a}}, \mathrm{S}_{\mathrm{b}}, \mathrm{S}_{\mathrm{c}}\right)$.

\section{RESULTS AND DISCUSSION}

To verify the performance of these continuous and discontinuous modulating signals based PWM techniques MATLAB based simulation studies are carried on vector controlled multilevel inverter fed induction motor drive. For the simulation studies, the parameters of the induction motor are chosen as $R s=1.57 \Omega, R r=1.21 \Omega, L m=165 \mathrm{mH}$, $L s=170 \mathrm{mH}, L r=170 \mathrm{mH}$ and $\mathrm{J}=0.089 \mathrm{Kg}-\mathrm{m}^{2}$. The switching frequency is taken as $3 \mathrm{kHz}$. The steady state plots of modulating signal, line voltage, stator currents, speed and electromagnetic torque of three and five level inverter fed vector controlled induction motor drive are shown from Fig. 5 to Fig. 8. Along with these, the harmonic spectra of line current are also shown in Fig. 6 and Fig. 8. From the results it is observed that with discontinuous modulating signal based PWM techniques reduce the switching losses as modulating signal is clamped for duration of $120^{\circ}$ either to positive or negative DC bus. It is observed that the magnitude of voltage levels are small and number of voltages levels are more in line voltages of five-level diode clamped multilevel inverter when compared with three-level diode clamped inverter. Hence, the harmonic content present in the line current of five-level diode clamped multilevel inverter is less and hence, the THDs of line current showed in Fig. 8 are low when compared with Fig. 6. The THD of line currents with various PWM techniques for three-level and fivelevel diode clamped multilevel inverters are tabulated in Table 4.

Table 4 THD of line currents

\begin{tabular}{|c|c|c|}
\hline $\begin{array}{c}\text { Type of } \\
\text { PWM } \\
\text { technique }\end{array}$ & $\begin{array}{c}\text { Three-level } \\
\text { inverter }\end{array}$ & $\begin{array}{c}\text { Five-level } \\
\text { inverter }\end{array}$ \\
\hline SVPWM & 3.02 & 1.56 \\
\hline DPWMMIN & 4.30 & 2.36 \\
\hline DPWMMAX & 4.29 & 2.36 \\
\hline DPWM0 & 5.42 & 2.37 \\
\hline DPWM1 & 4.40 & 2.49 \\
\hline DPWM2 & 4.63 & 2.38 \\
\hline DPWM3 & 4.62 & 2.45 \\
\hline
\end{tabular}

From the Table 4, it is observed that discontinuous modulating signal have high current ripple (i.e THD) when compared with continuous modulating signal based PWM techniques for both three and five level diode clamped inverters. Though the current ripple is high, the discontinuous modulating signal based PWM techniques show significant reduction in switching losses. From the Table it is observed that among the discontinue modulating signal based PWM techniques DPWMMIN shows superior performance in reducing current ripple. 

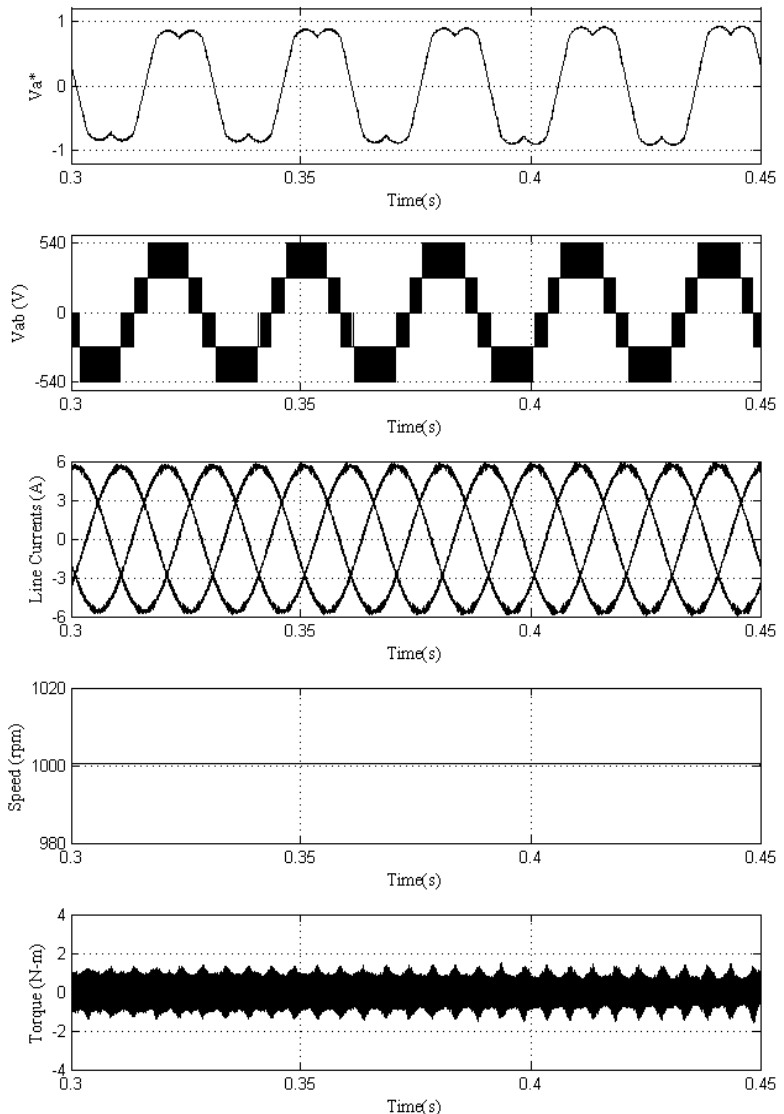

(a)
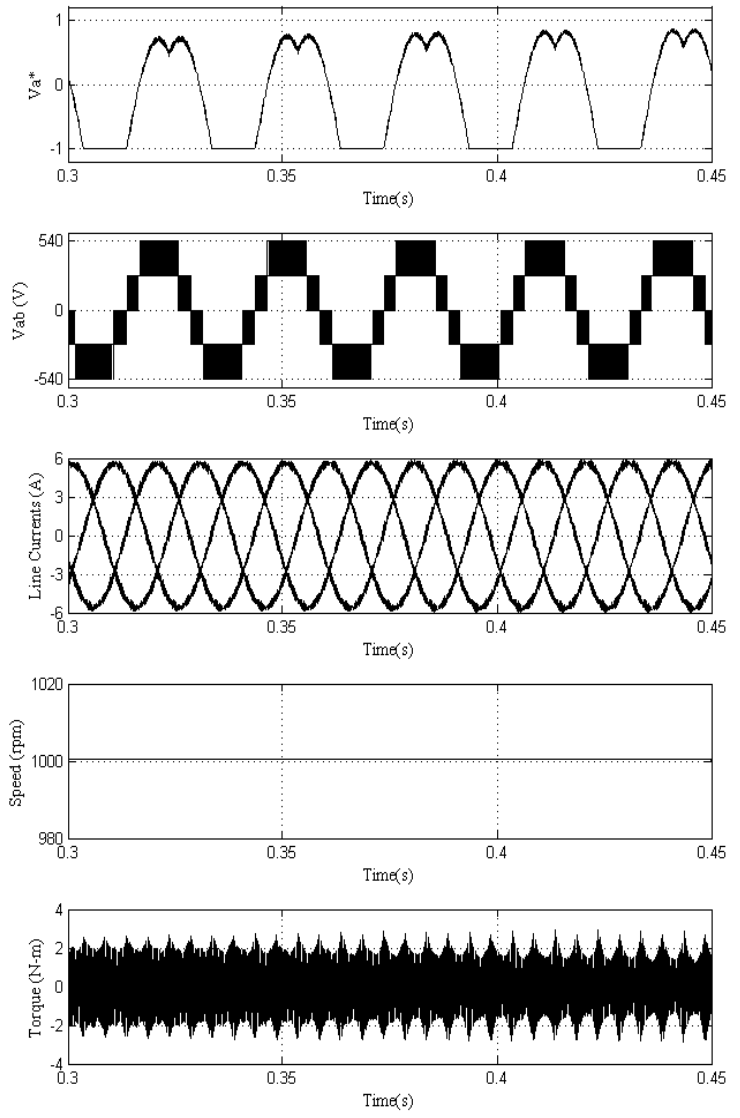

(b)

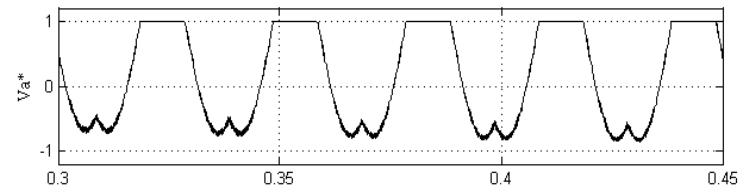

Tima(s)
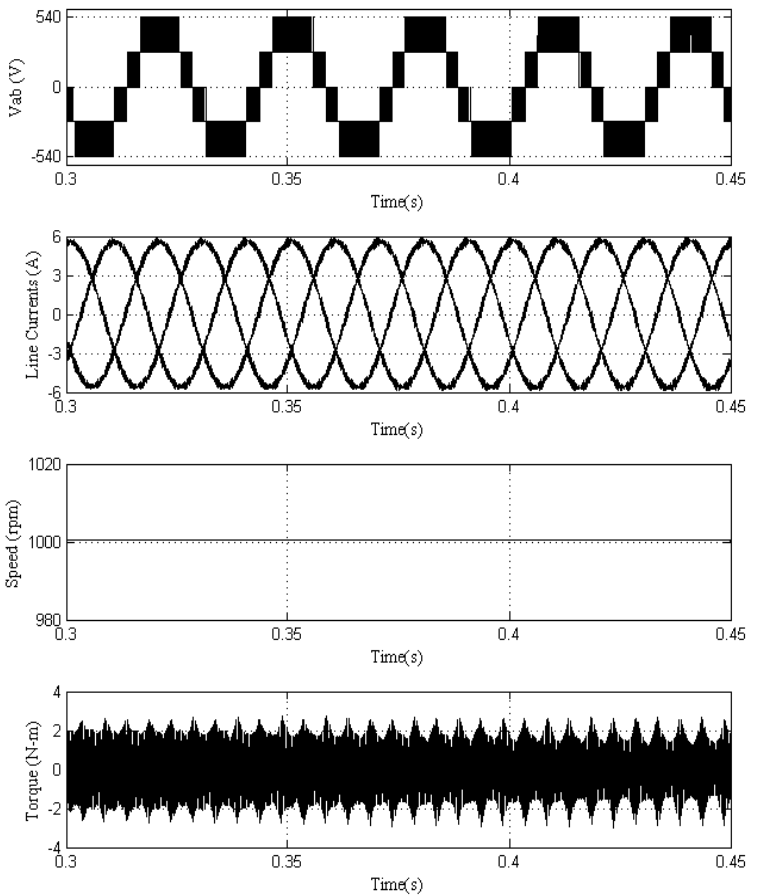

(c)
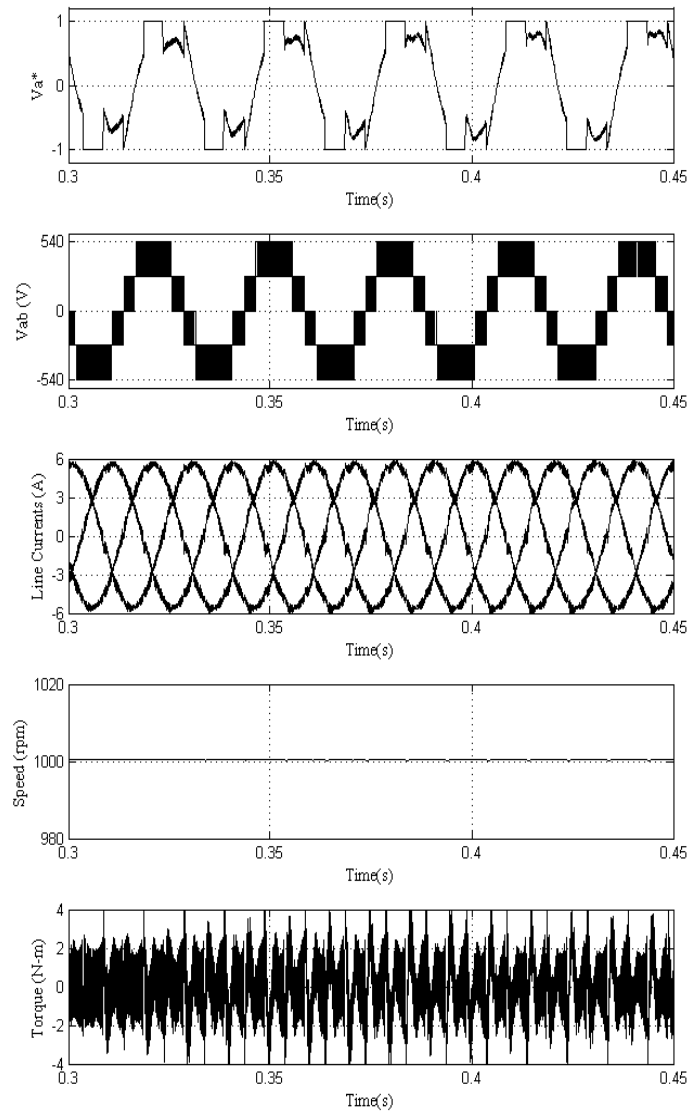

(d) 

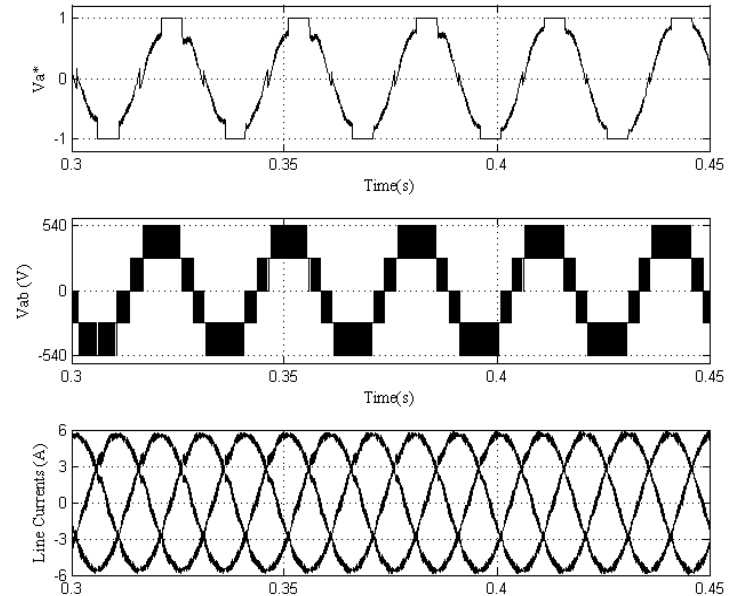

Tims(s)
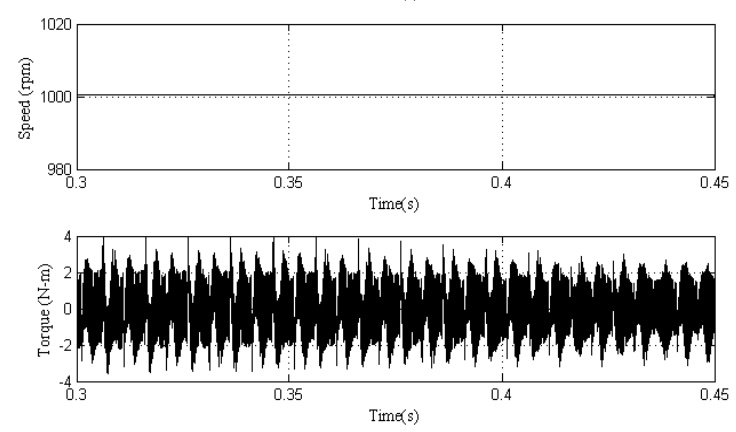

(e)
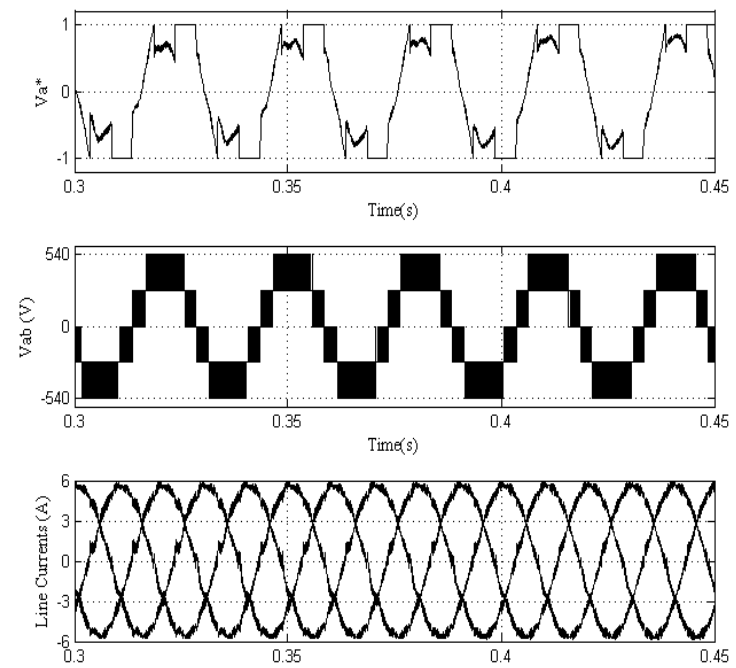

Times
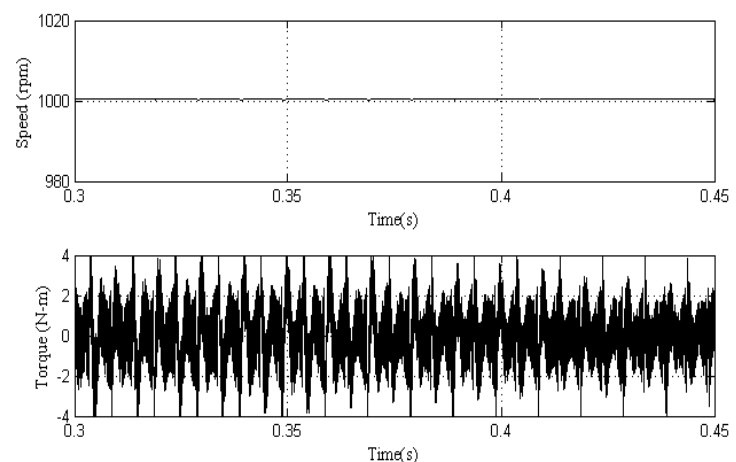

(f)
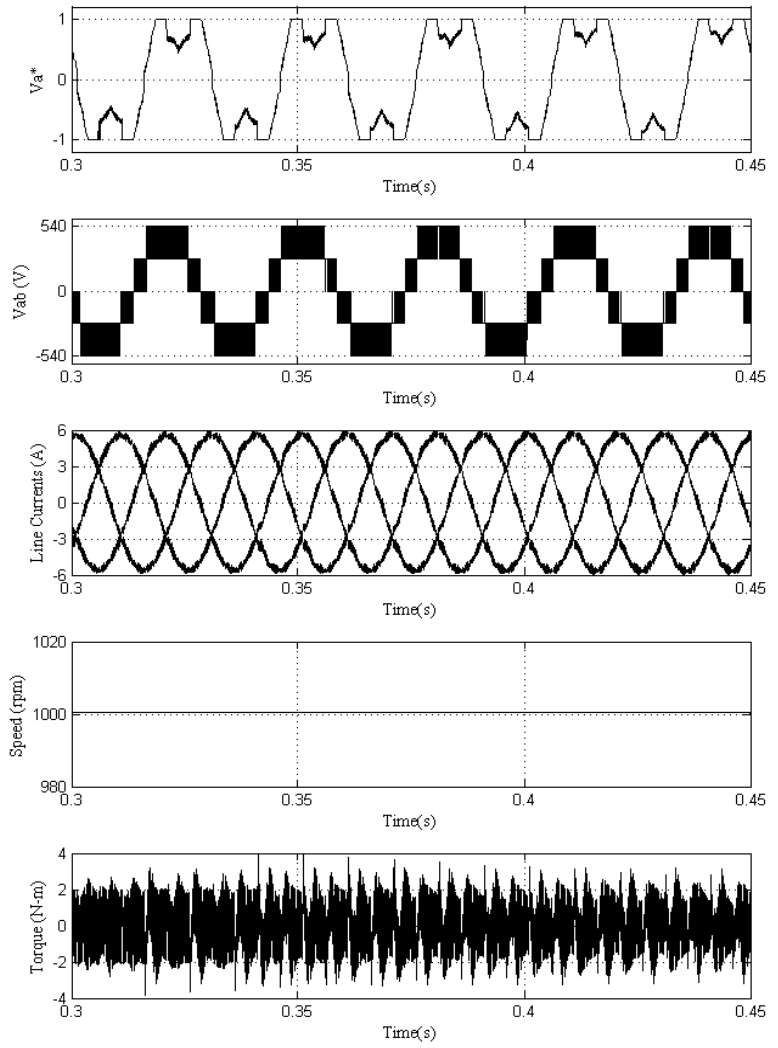

$(\mathrm{g})$

Fig. 5 Steady state response of various plots of vector controlled three-level inverter fed induction motor drive with (a) SVPWM (b) DPWMMIN (c) DPWMMAX (d) DPWM0 (e) DPWM1 (f) DPWM2 (g) DPWM3 techniques

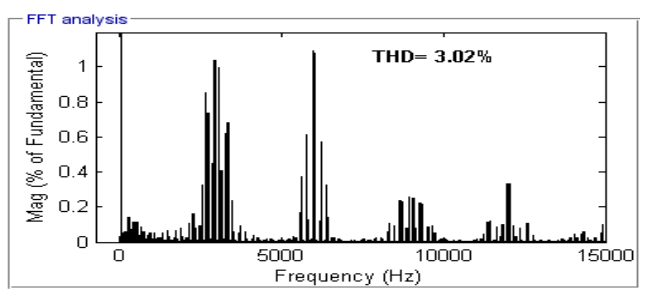

(a)

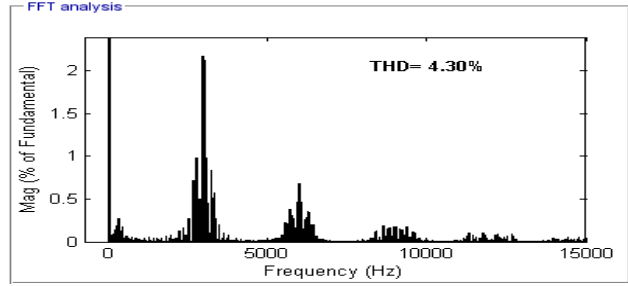

(b)

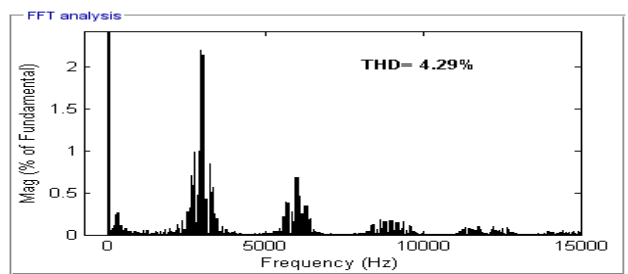

(c)

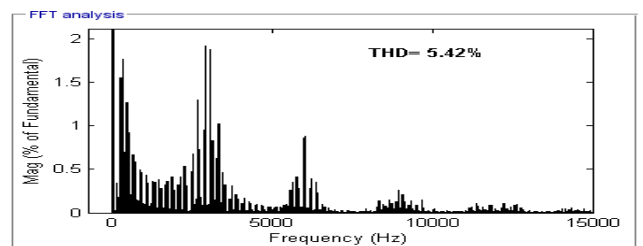

(d) 


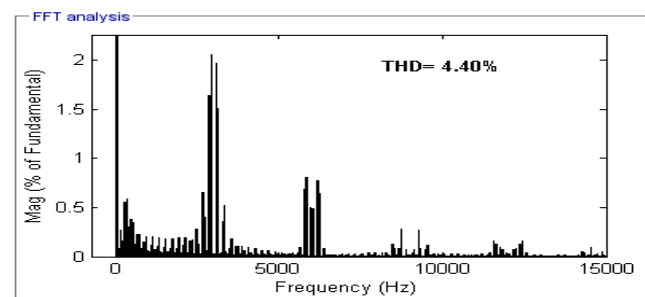

(e)

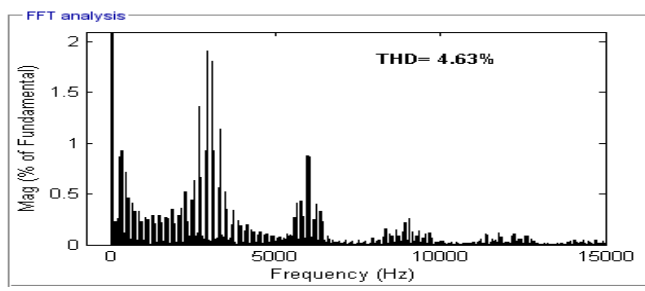

(f)

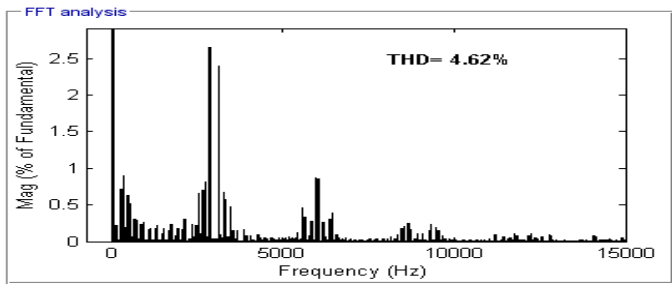

(g)

Fig. 6 Harminic spectrum of line current of vector controlled three-level inverter fed induction motor drive with (a) SVPWM (b) DPWMMIN (c) DPWMMAX (d) DPWM0 (e) DPWM1 (f) DPWM2 (g) DPWM3 techniques
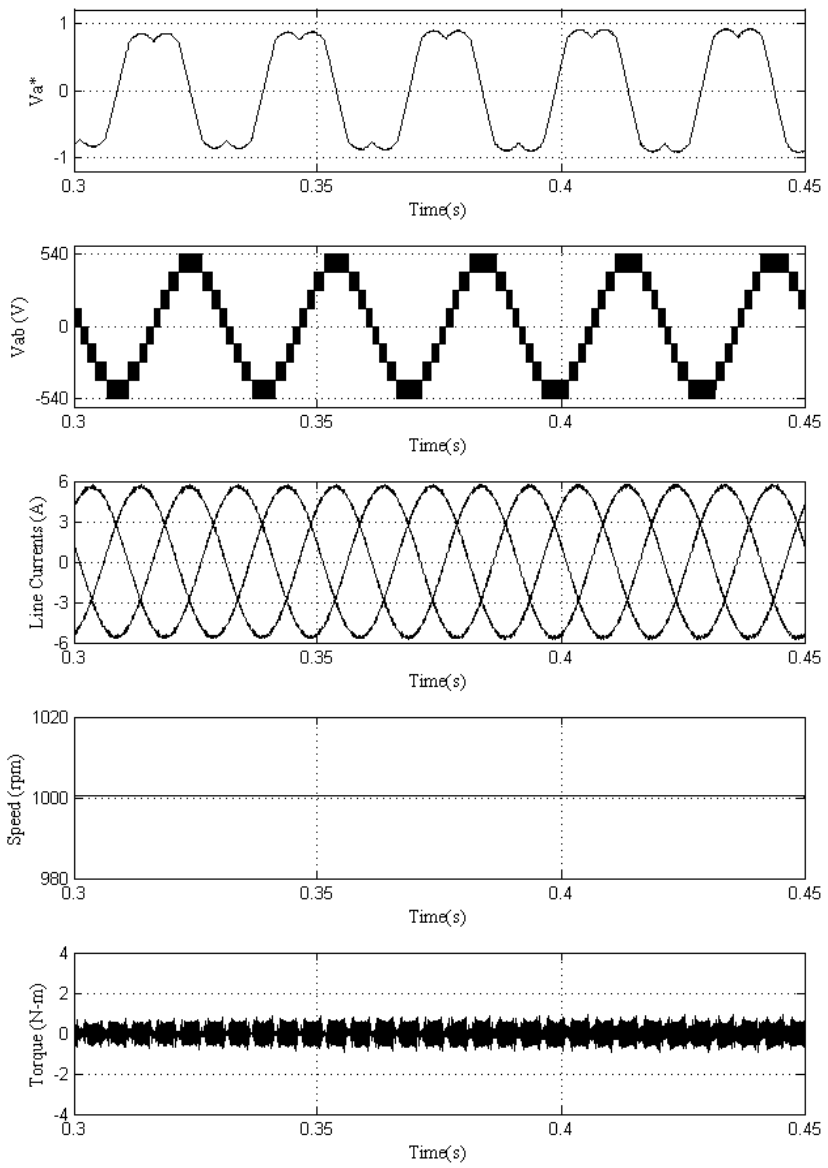

(a)


(b)
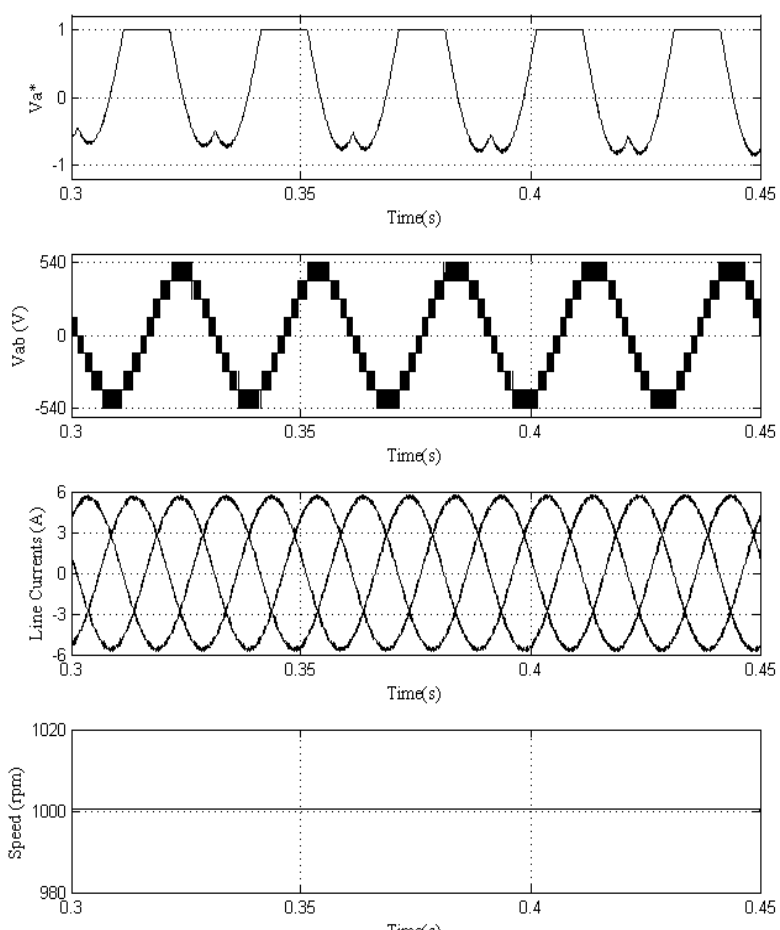

Times

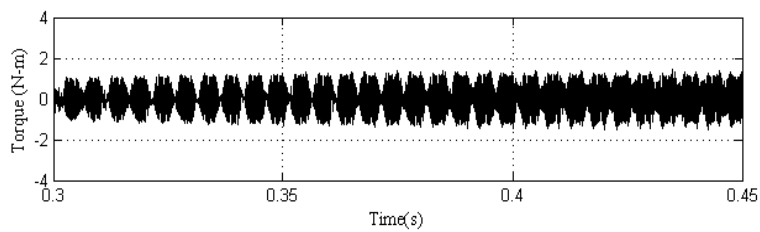

(c) 

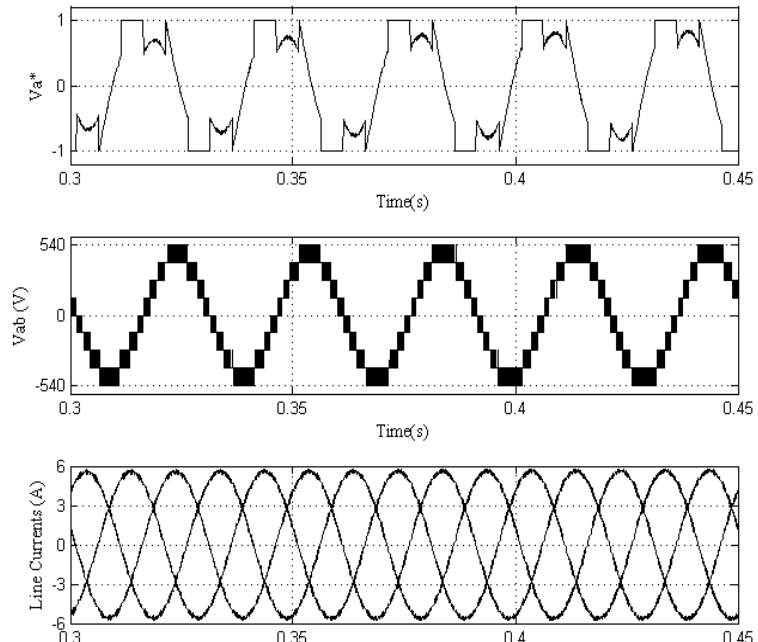

Tim(s)
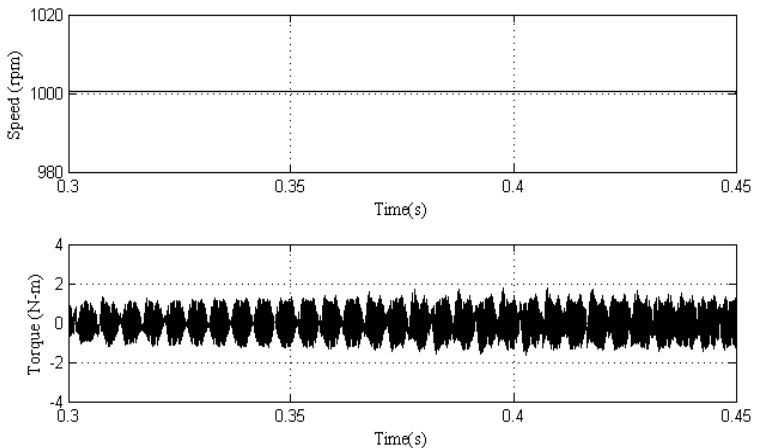

(d)
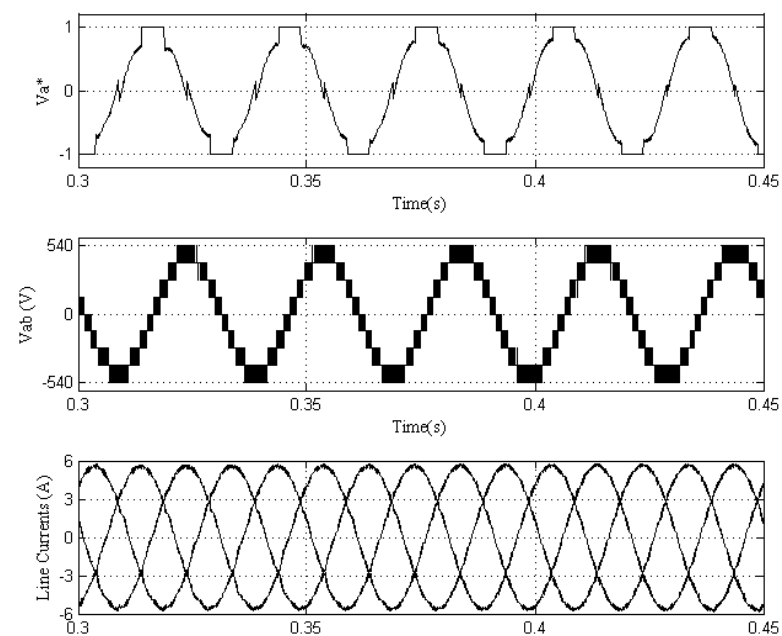

$\operatorname{Tim}(s)$
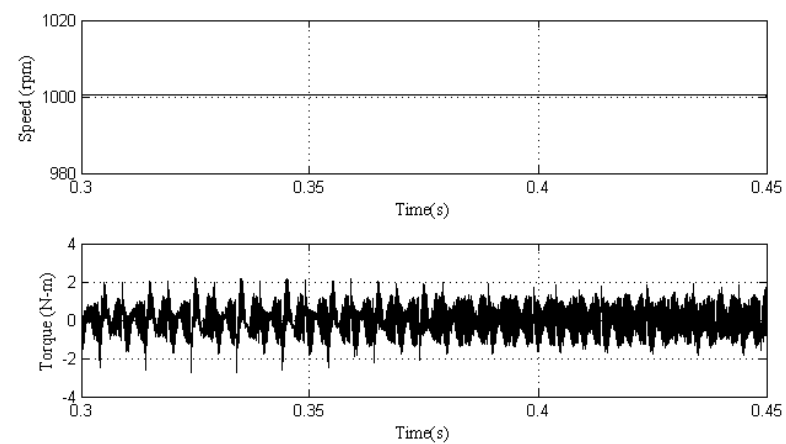

(e)
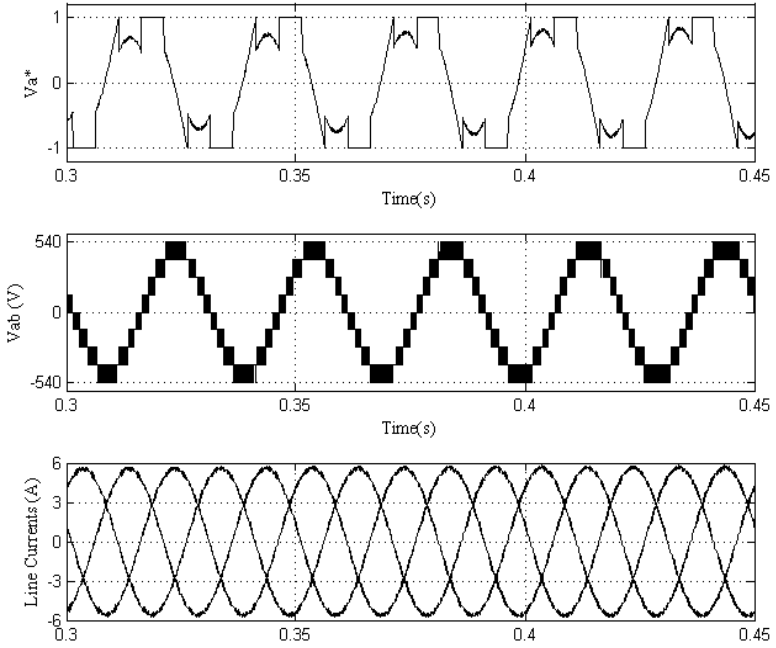

Timás)
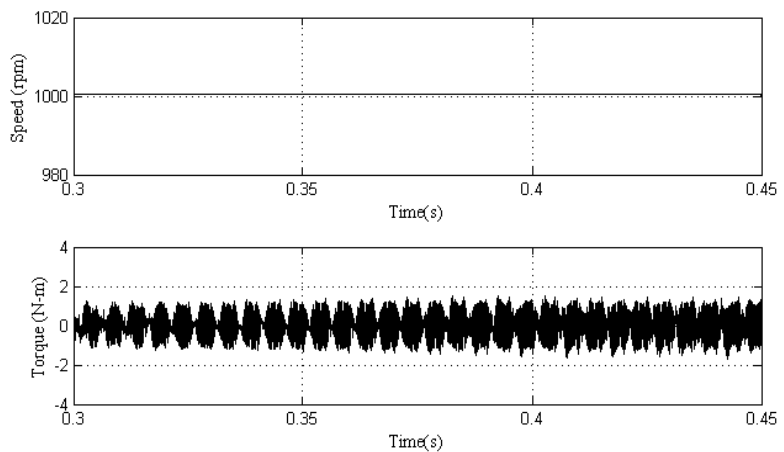

(f)
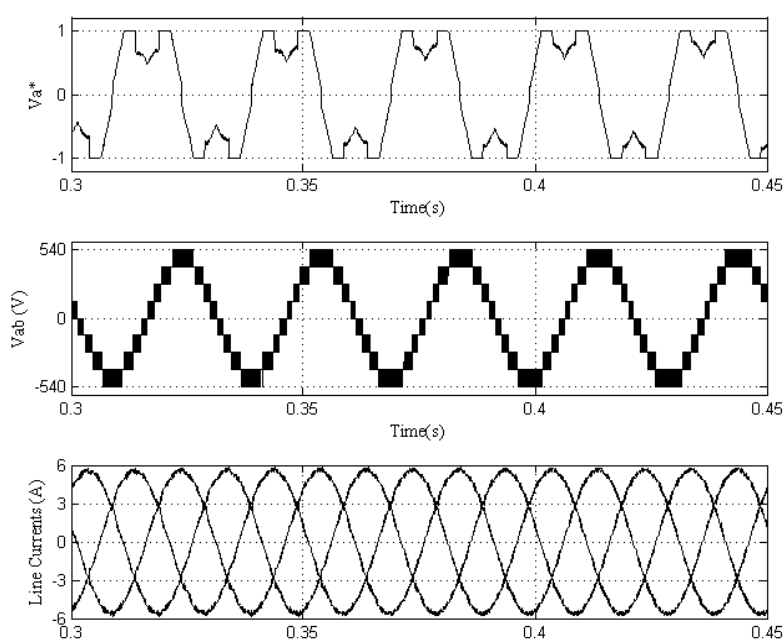

$\operatorname{Tim}(s)$
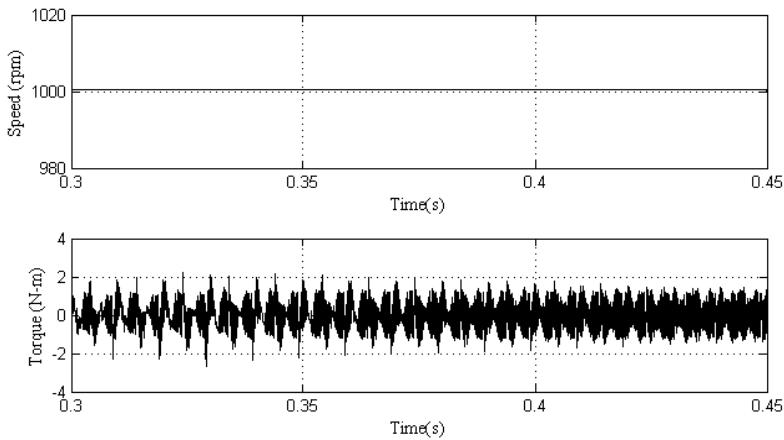

(g)

Fig. 7 Steady state response of various plots of vector controlled five-level inverter fed induction motor drive with (a) SVPWM (b) DPWMMIN (c) DPWMMAX (d) DPWM0 (e) DPWM1 (f) DPWM2 (g) DPWM3 techniques 


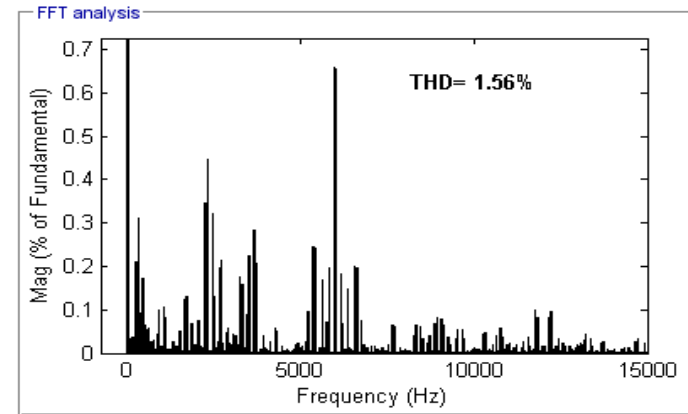

(a)

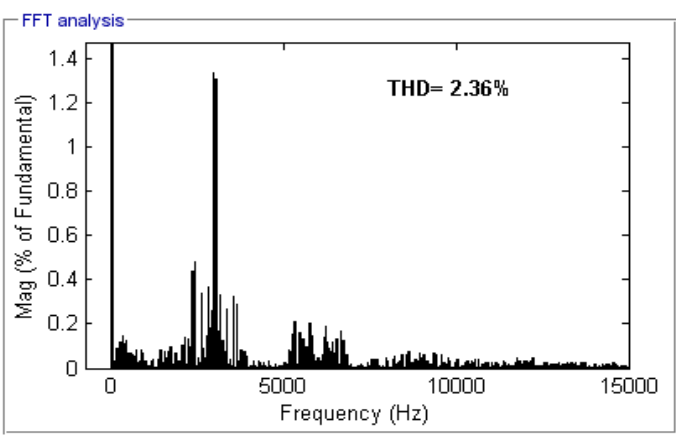

(b)

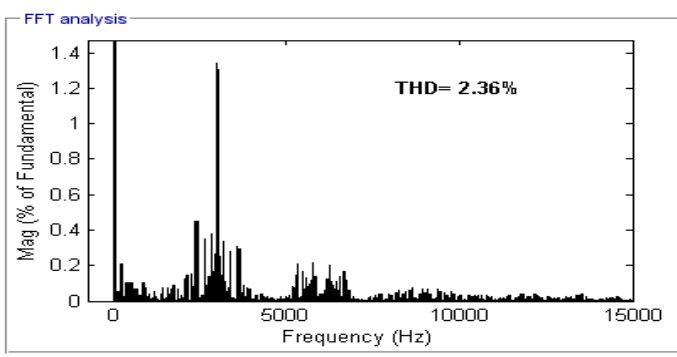

(c)

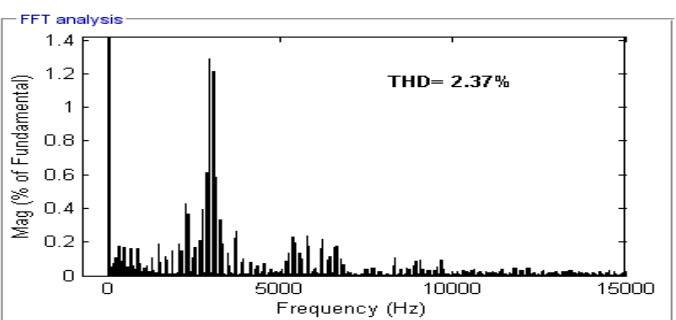

(d)

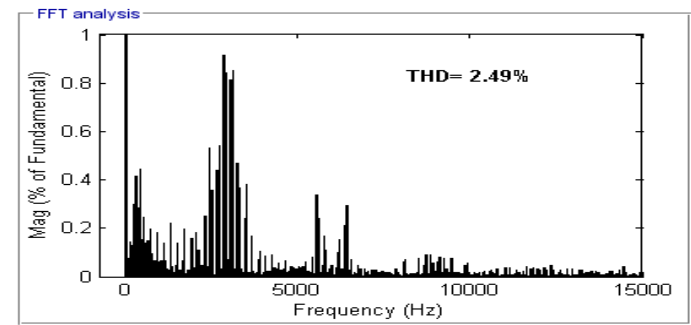

(e)

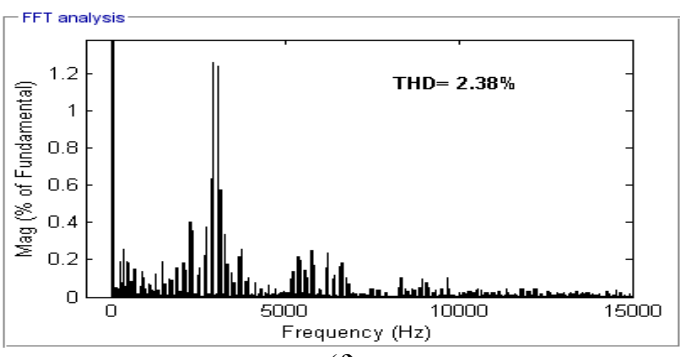

(f)

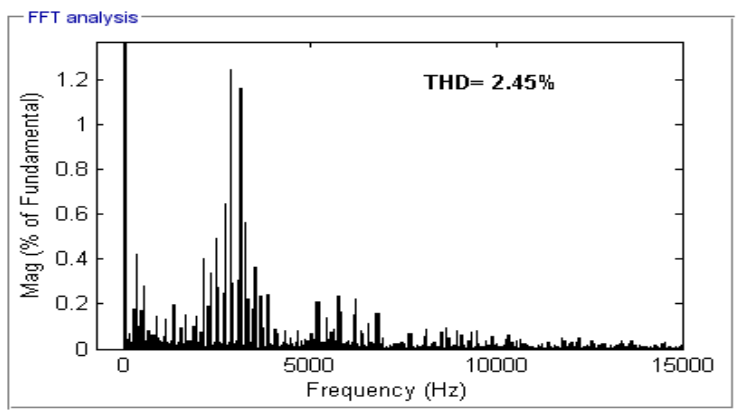

(g)

Fig. 8 Harminic spectrum of line current of vector controlled five-level inverter fed induction motor drive with (a) SVPWM (b) DPWMMIN (c) DPWMMAX (d) DPWM0 (e) DPWM1 (f) DPWM2 (g) DPWM3 techniques

\section{CONCLUSIONS}

In this paper different types of continuous and discontinuous modulating signals based scalar PWM techniques were proposed for three and five-level diode clamped multilevel inverter topologies. The implementation of these PWM techniques were carried out based on scalar carrier comparison approach. Hence, the implementation of these PWM techniques do not require sector identification and reference voltage vector magnitude calculations. The proposed PWM techniques are validated through numerical simulations on vector controlled drives. From results, it is concluded that the THDs of line current reduces as the number of levels increases. Moreover, the DPWM techniques results in slightly increased current ripple with significant reduction in switching losses.

\section{REFERENCES}

[1] BLASCHKE, F.: The principle of field orientation as applied to the new transvector closed loop control system for rotating-field machines, Siemens Review, pp. 217-220, 1972.

[2] LEONHARD, W.: 30 years of space vectors, 20 years of field orientation, 10 years of digital signal processing with controlled AC-drives, a review (Part 1), EPE Journal, No. 1, pp. 13-20, July 1991.

[3] LEONHARD, W.: 30 years of space vectors, 20 years of field orientation, 10 years of digital signal processing with controlled AC-drives, a review (Part 2), EPE Journal, No. 2, pp 89-102, Oct 1991.

[4] MIN-SIK RHO - SAM-YOUNG KIM: Development of Robust Starting System Using Sensorless Vector Drive for a Microturbine, IEEE Trans. Ind. Electron., Vol. 57, No.3, pp. 1063-1073, March, 2010.

[5] BOLDEA, I. - COROBAN-SCHRAMEL, V. ANDREESCU, G.-D. - BLAABJERG, F. SCRIDON, S.: BEGA Starter/Alternator - Vector Control Implementation and Performance for Wide Speed Range at Unity Power Factor Operation, IEEE Trans. Ind. Applicat., Vol. 46, No. 1, pp. 150-158, Jan./Feb., 2010. 
[6] AMÉZQUITA-BROOKS, L. A. - LICÉAGACASTRO, J. - LICÉAGA-CASTRO, E. UGALDE-LOO, C. E.: Induction Motor Control: Multivariable Analysis and Effective Decentralized Control of Stator Currents for High-Performance Applications, IEEE Trans. Ind. Electron., Vol. 62, No. 11, pp. 6818-6832, Nov. 2015.

[7] NABAE, A. - TAKAHASHI, I. - AKAGI, H.: A new neutral-point-clamped PWM inverter, IEEE Trans. Ind. Appl., Vol. IA-17, No. 5, pp. 518-523, Sep./Oct. 1981.

[8] TOLBERT, L. M. - PENG, F. Z. - HABETLER, T. G.: Multilevel converters for large electric drives, IEEE Trans. Ind. Appl., Vol. 35, No. 1, pp. 36-44, 1999.

[9] RODRIGUEZ, J. - LAI, J. S. - PENG, F. Z.: Multilevel Inverters: A Survey of Topologies, Control and Applications, IEEE Trans. on Ind. Elec., Vol. 49, No. 4, Aug. 2002.

[10] MALINOWSKI, M. - GOPAKUMAR, K. RODRIGUEZ, J. - PÉREZ, M. A.: A Survey on Cascaded Multilevel Inverters, IEEE Trans. Ind. Electron., Vol. 57, No. 7, pp. 2197-2206, July 2010.

[11] RODRIGUEZ, J. - BERNET, S. - STEIMER, P. K. - LIZAMA, I. E.: A Survey on Neutral-PointClamped Inverters, IEEE Trans. Ind. Electron., Vol. 57, No. 7, pp. 2219-2230, July 2010.

[12] KANG, D. W. et al.: Improved carrier wave-based SVPWM method using phase voltage redundancies for generalized cascaded multilevel inverter topology, in Proc. IEEE APEC, New Orleans, LA, pp. 542-548, Feb. 2000.

[13] PAN, Z. - PENG, F. Z.: A Sinusoidal PWM Method With Voltage Balancing Capability for DiodeClamped Five-Level Converters, IEEE Trans. Ind. Applicat., Vol. 45, No. 3, pp. 1028-1034, May/June 2009.

[14] BEIG, A. R.: Application of three level voltage source inverters to voltage fed and current fed high power induction motor drives, Ph.D. dissertation, Indian Inst. Sci., Banglore, India, 2004.

[15] DAS, S. - NARAYANAN, G.: Novel Switching Sequences for a Space-Vector-Modulated ThreeLevel Inverter, IEEE Trans. Ind. Electron., Vol. 59, No. 3, pp. 1477-1487, Mar. 2012.

[16] DAS, S. - NARAYANAN, G. - PANDEY, M.: Space-Vector-Based Hybrid Pulse width Modulation Techniques for a Three Level Inverter, IEEE Trans. Power Electron., Vol. 29, No.9, pp. 4580-4591, Sep. 2014.

[17] HAVA, A. M. - KERKMAN, R. J. - LIPO, T. A.: Simple analytical and graphical methods for carrierbased PWM-VSI drives, IEEE Trans. Power Electron., Vol. 14, No. 1, pp. 49-61, Jan. 1999.
[18] ZHOU, K. - WANG, D.: Relationship between space-vector modulation and three-pahse carrierbased PWM: A comprehensive analysis, IEEE Trans. Ind. Electron., Vol. 49, No. 1, pp. 186-196, Feb. 2002.

[19] OJO, O.: The generalized discontinuous PWM scheme for three-phase voltage source inverters, IEEE Trans. Ind. Electron., Vol. 51, No. 6, pp. 12801289, Dec. 2004.

[20] Da SILVA, E. R. C. - Dos SANTOS, E. C., Jr. JACOBINA, C. B.: Pulse width modulation strategies, IEEE IE Magazine, pp. 37-45, 2011.

Received June 16, 2016, accepted November 24, 2016

\section{BIOGRAPHIES}

Pasupuleti Rama Mohan was born in Andhra Pradesh, India in 1978. He received B.E. degree in Electrical Engineering from Bangalore University, India in 1999 and M.Tech degree in Power Electronics from Visvesvaraiah Technological University, India in 2002. Currently he is pursuing his Ph.D. degree under JNT University, Anantapur, Andhra Pradesh, India. He has published more than 10 papers in various international and national journals and conferences. At present he is working as Associate Professor at Krishna's Pragati Institute of Technology (At present known as Sri Prakash College of Technology), Rajahmundry, Andhra Pradesh, India. His research interests are Power Converters, Industrial Drives.

Dr. Teegala Brahmananda Reddy was born in 1979. He graduated from Sri Krishna Devaraya University, Anantapur in the year 2001. He received M.E degree from Osmania University, Hyderabad, India in the year 2003 and Ph.D from J.N.T.University, Hyderabad in the year 2009. He is presently Professor and Head of Electrical and Electronics Engineering Department, G. Pulla Reddy Engineering College (Autonomous), Kurnool, India. He presented more than 100 research papers in various national and international conferences and journals. His research areas include PWM techniques, DC to AC converters and control of electrical drives

Dr. Mallapu Vijaya Kumar graduated from NBKR Institute of Science and Technology, Vidyanagar, A.P, India in 1988. He obtained M.Tech degree from Regional Engineering College, Warangal, India in 1990. He received Doctoral degree from JNT University, Hyderabad, India in 2000. Currently he is working as Professor in Electrical and Electronics Engineering Department, JNT University, Anantapur, A.P, India. He is a member of Board of studies of S.V. University, Tirupathi and JNT University, Hyderabad, India. He has published over 40 research papers. He received two research awards from the Institution of Engineers (India). His areas of interests include Electrical Machines, Electrical Drives, Microprocessors and Instrumentation. 